\title{
EXPERIENTIAL MARKETING AND CUSTOMERS RELATIONSHIP MARKETING IN CREATING CUSTOMER VALUE (Customer Survey of 3, 4 and 5 star Hotels in the West Java Province, Indonesia)
}

\author{
Ananta Budhi Danurdara \\ Lecturer of Bandung Institute of Tourism \\ Jl. Dr. Setiabudhi 186 Bandung 40141, West Java Indonesia \\ Email: ananta.budhi.d@gmail.com
}

\begin{abstract}
The research objective is to get empirical evidences as well as to elucidate the phenomenon so that conclusion can be drawn concerning the implementation of Experiential Marketing and Customers Relationship Marketing in Creating Customer Value at stars hotel of 3, 4 and 5 in the West Java Province. The research results is expected to be beneficial to the practice of business and hopefully it will also contribute to the to the development of management science, especially marketing management.

This study uses quantitative approach while the method is descriptive inductive involving data collecting, presenting, analyzing, followed by hypothesis testing, and drawing conclusions and suggestions. Followings are research conclusions:

1. Application of experiential marketing at 3,4 and 5 star hotel in West Java province according to new customers perception belongs to 'quite good' category.

2. Application of customer relationship marketing at 3, 4 and 5 star hotel in the West Java province according to new customers perception belongs to 'quite good' category.

3. Application of customer value at 3,4 and 5 star hotel in the West Java province in overall clasified into 'quite good' category as perceived by new customers.

4. Implementation of experiential marketing and customer relationship marketing significantly affect customer value of 3,4 and 5 star hotel in the West Java province.

The research results confirmed the importance of experiential marketing and customers relationship marketing implementation since it can increase customer value, and it also has implications for customer loyalty of of 3,4 and 5 star hotel in the West Java Province.
\end{abstract}

Keywords: Experiential Marketing, Customers Relationship Marketing, customer value

\section{INTRODUCTION}

The tourism industry sector of Bandung city is significantly influential toward economic growth with a contribution to regional revenue of Bandung city in 2011, penetrating $40 \%$ of the total revenue [19]. Based on data from BPS West Java [20], there were 1,552 hotel and other accommodations that have been established in West Java. The number of rooms are as many as 43,981 hotel rooms and 72,105 beds. The increasing the number of hotels was due to a hospitality entrepreneurs business calculation that estimating the need for new hotels [22]. Unfortunately, this high number of hotel was not accompanied by high occupancy rates.

The low occupancy rate is largely due to the intense competition in the hospitality industry [21]. The fact that stars hotel rooms are unoccupied is caused by tourists are distributed to new hotels as well as other accommodation estabslishments as the result of increasing number of construction and operating permits of new hotels around in the West Java province Furthermore, this is even getting worse by the presence of several apartments in Bandung and other cities whose room converted as hotel [22]. Intense competition and the low occupancy rate of the hotel rooms makes the hotel companies need to think about the right strategy to increase the number of visits and the occupancy of hotel rooms.

Based on the preliminary survey results concering 50 respondents in several hotels in the West Java province during June to August 2014 it is identified that that the hotel occupancy can not be separated from customers unique experience during the stay. In intense competition, the priority should be given to customer satisfaction, so that companies can survive, compete and dominate market share [5].

In the context of this research, customer relationship marketing can provide benefits to customers as well 
creating competitive barriers for competitors, thus enabling companies to improve customer satisfaction. Hotel is a type of business services, where customers will pay attention to the physical environment as one of the factors prior to deciding to stay at the hotel. Therefore, the physical environment of the hotel such as comfortness, temperature, music, cleanliness, and well organized layout with high aesthetic value, not to forget the use of technology influence on customer satisfaction and loyalty.

Factors such as the increasing number of competitors, technological sophistication and increased education about marketing accelerates and encourage marketers to be creative to market their products.[18] cited Sanders, director of Yahoo, states that the experience is the basis of a new economy for all industries. Further Sanders stated that today is the time to experience economy. Regardless of the product or service being sold, a marketer needs to provide an unforgettable experience for customers because it is the one that is highly valued.

According to[4] the success of a company's internal plan, especially related to strategic planning in the field of marketing and services there are 2 (two) devices, namely hardware and software. The next four elements are style, skills, staff, and shared values. All are the "software" is indispensable in providing excellent service experience for customers.

[13] states that a company needs to establish a accurate marketing and service strategy, because if not, companies will lose in the competition to grab market share. Customers will see the physical environment (physical evidence) as a guide to the quality of a company. [10] argues that the tangible aspects is the main attributes that influence the decision to stay at the hotel.

The research raises the issue of experiential marketing with a case study on star hotels of 3,4 and 5 in the West Java province. The low occupancy rate of star hotels in the West Java province is possibly caused by inappropriate marketing strategy to meet the needs and desires of consumers and to be able to provide a unique experience for the consumer. Based on the above assumption it is necessary to do an in-depth study on the implementation of experiential marketing at star hotel that will also measure its effect in increasing hotel customer value, [1] states that sense marketing of experiential marketing can positive effect on customer value.

The competitive environment requires the implementation of customer relationship marketing. Therefore in this study hotel marketing strategies related to customer relationship marketing should be examined in depth to attract, retain, and maintain good relations with customers that enable to deliver value to customers and maintain customer loyalty.

Customer perception of the value is described as a comparison between the quality or benefits they feel in a product with the sacrifices they feel when paying the price of the product. Customer value is defined as "the difference between benefits with the sacrifices (cost or sacrifices). Or in other words, consumers compare the benefits over sacrifices incurred in buying the product or service. The formula is:

\section{VALUE = Total Benefit - Total Cost}

In relation with the above discussion this study focused to determine how much influence of experiential marketing, customer relationship marketing to customer value hotel in the West Java Province.

This research was conducted only in star hotels of 3, 4, and in the West Java province. The reasons are, among others: supporting facilities hotels 3, 4, and 5 starr are relatively similar such as a restaurant, pool, and room facility has been standardized. In addition to that marketing programs and marketing efforts are done adequately and more freely in 3, 4 and 5 star hotels. Moreover, consumers prefer to stay in star hotels by reason of pride and privacy that consumers have when staying in 3, 4, and 5 star hotels.

Seeing the above reasons the writer feels it is necessary to do research on experiential marketing, customers relatioship marketing in realizing customer value, in 3, 4, and 5 star hotels in the West Java province, and the title formulae is as follow: Experiential Marketing and Customer Relationship Marketing Against Customer Value Customer (A Survery of Customer Star Hotels of 3, 4, and 5 in West Java Province)

\section{Formulation of the problem}

Based on the identification of the problems above, in this study the formulation of the problem is as follows: How much simultaneous influence of experiential marketing and customer relationship marketing toward customer value is star hotels of 3, 4 and 5 in West Java Province.

\section{Objectives and Benefits Research}

Along with the identification and formulation of problems above the purpose of this study is to analyze and determine the influence of simultaneous experiential marketing and customer relationship marketing toward customer value in star hotels. The purpose of this study are expected to provide scientific theoretical contribution, especially in the development of economics and marketing management services using approaches and methods in order to explore and 
find new approaches in the implementation of marketing methods in the world the hospitality industry, especially in the concept:

1. Marketing experiential of the hotel, which is related to the utilization dimensions / indicators: sense, feel, think, act, and relate marketing.

2. Customer relationship marketing of the hotel, which is related to the utilization dimensions / indicators: understanding customer expectation, partnership building service, total quality management, and empowering employees.

3. Customer value of the hotel, which is related to the utilization dimensions / indicators:

(1). The total customers value includes all the value derived from the product (product value), the value of the service (service value), the sales personnel (personnel value), and the company's image (image value), as well as

(2). The total costs include the price paid (monetary price) by the customer, the cost of time (time cost), the cost of energy expenditure (energy cost), and the cost of psychological (psychic cost).

\section{Literature Review}

\section{Experiential Marketing}

The concept of experiential marketing according to

[14] is divided into two major parts, namely:

\section{Strategic Experiential Marketing}

it approaches the whole experience of the senses, feelings / affection, cognition, physical and lifestyle, as well as the relationship with the culture or certain references which eventually able to give an imagination that affect the emergence of the value of experience in a product or service. Strategic Experiential Marketing encompasses such dimensions as: Sense Marketing, Feel Marketing, Think Marketing, Act Marketing and Relate Marketing.

2. Experiential Provider

that is component that enables the formation memorable experience that includes communications, visual identity, product presence, co-branding, spatial environment, web sites and people.

Experiential marketing according to [16] is a marketing approach that provides an exceptional framework for integrating elements of experience and entertainment into product / service.

Experiential marketing strategy seeks to create a positive experience for consumers to a product or service that can be used as a reference for marketers to predict future consumer behavior in the form of repurchasing actions. In this case the emotional side of the products developed through marketing efforts. Marketers can use experiential marketing to try to understand, interact with consumers and empathize with their needs. With this strategy is expected customers will be satisfied even loyal, willing to do a long-term relationship, using the company's products and services continuously and recommendd the product or service to friends and those closest to them. [12], experiential marketing is the ability of a product to offer emotional experience to touch the hearts and minds of consumers.

\section{Experiential marketing dimensions}

[11] states that the experiential marketing consists of five (5) dimensions, namely:

\section{Sense Marketing.}

Sense marketing is one of the ways used to touch the emotions of customers by providing an experience that can be obtained by consumers through their senses about product and service [10]. For example, when customers enter into a hotel, the eye will see the attractiveness of hotel decor and layout, fresh and clean of hotel rooms, and the delicious taste of food served in the hotel restaurant. Sense marketing can be a positive or negative effect on loyalty.

Three key strategies that can be used to stimulate the marketing sense: sense as differentiator, sense as a motivator, a sense as value providers [11].

2. Feel Marketing

Feel marketing is a type of experience that appears to touch the deepest feelings and emotions of customers with the aim of creating an effective experience. Feel to do with excellent service such as the hospitality and courtesy of employees.

3. Think Marketing

Think marketing is one way that companies do to transform a commodity into the experience by performing customization continuously [14].

In think marketing there are two concepts i.e. Convergent Thinking and Divergent Thinking.

4. Marketing Act

Act marketing is part of the Strategic Experiential Modules (SEMs). Act marketing is designed to create consumer experiences in relation to the physical body, lifestyles, and interactions with others. For example, in the hospitality services are welcoming guests in friendly manner, etc.

5. Relate marketing

Relate marketing is part of the Strategic Experiential Modules (SEMS). Relate marketing combines aspects of sense, feel, think, and act with the intention of linking the individual with what exists outside of him or herself and implement 
relationships between other people and other social groups so that they feel proud and welcome in the community. An examples of relate marketing is when hotel "X" cooperating with agencies or other companies, so as to create a positive image in the public eye.

\section{The Concepts of Customer Relationship Marketing}

Customer relationship marketing says to deliver value to customers requires customer relationship marketing that focuses on the customer in the long term [2]. Customer relationship marketing pays attention to the ongoing transactions, establish, maintain and strengthen relationships with customers as the basis for an ongoing relationship (long-term relationship).

\section{Customer Relationship Marketing Dimensions}

[11] states that customer relationship marketing consists of several dimensions, namely understanding customer expectation, partnership building service, total quality management, and empowering employees.

Indicators of this variable is:

a. Employee responsibilities in resolving the problem.

b. The company's ability to provide conducive environment and working atmosphere for employees.

c. The ability of employees to solve problems.

\section{Consumer Purchase Behavior}

According to [14] consumer behavior is the final purchasing behavior of consumer, both individuals and households, which buy products for personal consumption and there are four factors that can influence the purchasing behavior of consumers, namely: cultural factors, social factors that include personal factors includes (age and lifecycle, employment, economic situation, Lifestyle, Personality and Self-concept), and Psychological factors.

According to [2], there are several factors that influence purchasing decisions, among others: consumer Psychological and socio-cultural environment.

\section{The concept of Customer Value}

[13] states that the value received by customers is the difference between total customer value and total customer cost.

Thus the value can be formulated as follows

$$
\text { Value }=\frac{\text { Benefit }}{\text { Cost }}=\frac{\text { Functional Benefit and Emotional Benefit }}{\text { Monetery cost }+ \text { Time cost }+ \text { Energy cost }+ \text { Psychic cost }}
$$

Products purchased from the company by the buyers are products that offer value to the customer (customer delivered value) the highest. Value for the customer (customer delivered value) is the difference between total customer value and total customer cost. Total customer value is a set of benefits expected by customers of certain product or service. Total customer costs is a set of expected costs incurred by customers to evaluate, acquire, use, and dispose of the product or service. Determinants of value provided to customers as the following picture:

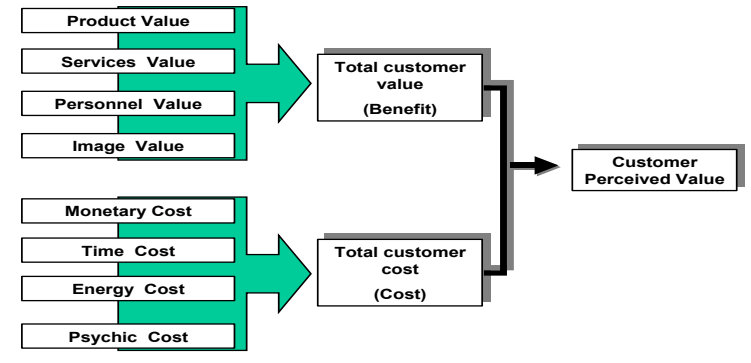

Firgure 1:

Sumber : Kotler, Manajemen Pemasaran, 2010

Determinants of value for customers

[8] explains that the perception of value is subjective and individual. Further, he said that the value is all that I get for all that I give. From the statement customers perceive that the value of the overall customer perception on the usefulness of a product essential to what he gave to what he received, although this perception varies, since everyone can have a different perception (some tends to volume, high quality or comfort), while there are some customers that include also the time and effort into the amount of the costs incurred. [8] also divide the values into 4 (four) meaning: The value is a low price, value is the quality that is obtained from the price obtained, value is what you want in products and services, value is what is gained from what is given. According to[15], the dimensions of customer value are Emotional value, Social value, Quality / performance value, and Price value for money.

\section{Variable of Customers Value}

[11]states that the concept of value from a marketing perspective is divided into three groups: customer value as "a function of", customer value as "a ratio", and the value of the customer as "a difference ".

\section{Dimensions of Customer Value}

[13], total customer value includes all the value derived from the value of the product (product value), the value of the service (service value), the sales personnel (personnel value), and the company's image (image value ). 
The total costs include the price paid (monetary price) by the customer, the cost of time (time cost), the cost of energy expenditure (energy cost), and the cost of psychological (psychic cost).

\section{Research Framework}

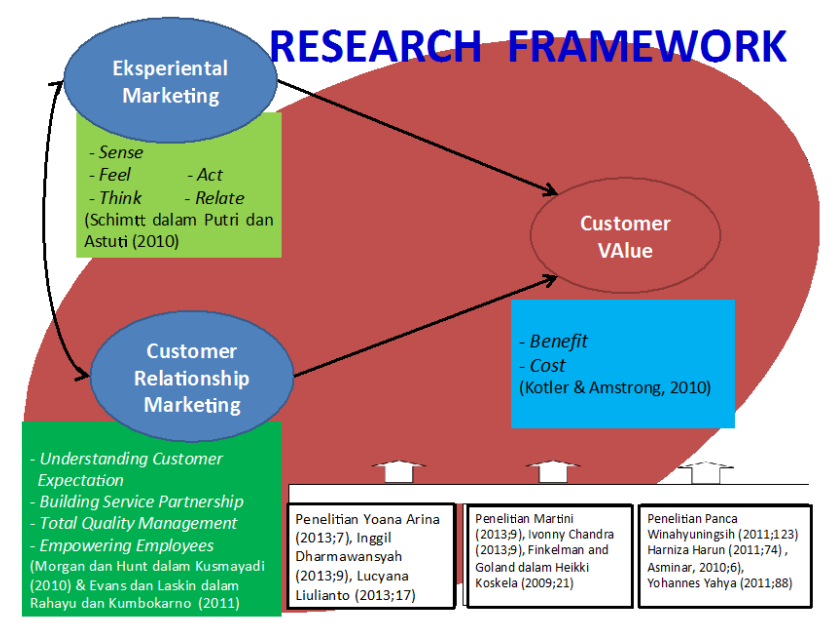

Figure 2

Research Paradigm (influence among Variables)

\section{Research hypothesis}

Based on the description of the background, the formulation of the problem, and thinking framework of the above the hypotheses of this study can be formulated as follows:

$\mathrm{H} 1$ : experiential marketing and customer relationship marketing influence simultaneously toward customer value of stars hotel.

\section{METHOD}

The method used in this research is survey method with descriptive approach to answer the research objectives concerning customer assessment of the application of marketing experiential concepts, customer relationship marketing and customer value at stars hotel in the West Java province which is carried out through data collection in the field from the respondents with a certain number of samples. Especially to answer the purpose of research on the influence of experiential marketing and customer relationship marketing towards customer value in stars hotel in the West Java province carried out using the verification method approach.

\section{Research design}

This study was a causal type design, which is to identify the cause and effect relationship between variables and researchers are looking for the real type of facts to help understand and predict relationships [6]. The problem presented in this study is a problem that is recommended by the previous investigators, who need support for the latest facts.

\section{Operationalization of Variables}

Variables to be analyzed in this study are:

Experiential marketing (EM): as an exogenous variable

Customers relationship marketing (CRM): as an exogenous variable

Customer Value (CV): as the endogenous variable (intervening / mediator)

Experiential marketing was adopted and modified using the terms and definitions based on [3] his study, the dimensions of Ekperiental Marketing measurement are: (1) Sense; (2) Feel; (3) Think; (4) Act; (5) Relate. Customer Relationship Marketing -CRM refers to "all marketing activities directed toward establishing, developing and maintaining succesfult relational exchange". Adopted and modified using the terms and definitions based on [23]. In this study, the dimensions are Understanding Customer Expectations, Building Service Partnership, Total Quality Management, Empowering Employees.

Cusomer Value - CV is the difference between the prospective customer's evaluation of all the benefits and all the costs of an offering and the perceived alternatives. was adopted and modified using the terms and definitions based on [13]. In thi study, the dimensions are Benefit and Cost.

\section{Population and Sample Research}

The population in this study is the hotel customers / tourists that have used and who was a hotel room occupants of 3, 4, and 5 stars hotel in West Java Province. Based on the data obtained from the results of a preliminary survey in July 2014 in several hotel in West Java province is known that hotel customers of 3,4 , and 5 stars hotel for the year 2013 were as many as 74,905 , with the composition as shown in the following table.

\section{Tabel 2}

Customer Composition of 3, 4, dan 5 Star Hotels in West Java Province

Year of 2013

\begin{tabular}{lllr}
\hline No & $\begin{array}{l}\text { Hotel } \\
\text { Classification }\end{array}$ & $\begin{array}{l}\text { Number of } \\
\text { Hotel }\end{array}$ & $\begin{array}{l}\text { Number of } \\
\text { Customers }\end{array}$ \\
\hline 1 & Star 3 & 38 & 37.453 \\
2 & Star 4 & 28 & 26.217 \\
3 & Star 5 & 11 & 11.236 \\
Total & & $\mathbf{7 7}$ & $\mathbf{7 4 . 9 0 5}$ \\
\hline
\end{tabular}

Method of sampling in this study were calculated using Stratisfied Proposionalle Cluster Random Sampling. [3], stratified sampling is taking samples 
with regard to the strata (levels) and classes of the population.

To determine the sample size, the Slovin formula is used [12]. After the calculation using the above formula it was found minimal sample size $n=203.571$ or rounded to $=204$. To meet the adequacy of the data, it was decided to have sample of 210 respondents, consisting of hotel customers that have used and who was a hotel room occupants of 3,4 , and 5 star hotels in the West Java province with the number of respondents represented each classification of hotel. Collection of field data in order to obtain primary data was done through: observation, deployment questionnaires, interviews and search and collecting documents.

\section{Testing Instrument Research}

In testing the validity of the instrument Product Moment Correlation was used [12]. Kreteria valid if $r$ arithmetic $>$ than $\mathrm{r}$ table, then the item is declared valid. The level of significance $\alpha=0.05$. Calculation of reliability of the instrument using Alpha Croncback formula. The result was the value of reliability coefficient of 0.60 was good enough to be used in research.

\section{Draft Analysis and Testing Hypotheses}

The next is to conduct verification testing to address the magnitude of the effect between these variables. In this study, analysis of verification done to get answers regarding the simultaneous effect of experiential marketing and customer relationship marketing to customer value at 3,4 and 5 star hotels in the West Java province. SPSS version 19 is used to prosess the gathered data.

\section{Analysis of Structural Equation Modeling (SEM)}

The selection of analytical techniques Structural Equation Modeling (SEM) based on the consideration that SEM has the ability to combine measurement models and structural models simultaneously and efficiently when compared with the technique of multivariate another [12]. Measurement models are used to determine the size of a construct that is latent variable.

\section{Results of Hypotheses Testing}

Research hypothesis testing was conducted to determine the clarity of the relationship and the degree of influence between variables.

The hypothesis to be tested in this study, as follows:

\section{Hipotesis}

$$
\begin{array}{cl}
\mathrm{H}_{0}: \text { all } \beta_{2 . i} \text { i } & \text { Experiential marketing and customer } \\
\& \gamma_{2 . \mathrm{i}}=0 & \text { relationship } \\
\mathrm{i}=1 \& 2 & \text { marketing does not have simultaneous effect }
\end{array}
$$

toward value of star hotels customers.

$$
\begin{array}{cl}
\mathrm{H}_{1}: \text { exist } \beta_{2 . \mathrm{i}} & \begin{array}{l}
\text { Experiential marketing and customer } \\
\text { relationship marketing influence }
\end{array} \\
\mathrm{i}=1 \& 2 & \text { simultaneously toward the value of star } \\
& \text { hotels customers }
\end{array}
$$

To test the hypothesis in this study whether exogenous variables affect the endogenous variables, we used multiple hypothesis testing, namely: Simultaneous hypothesis test (Test F)

The F-test statistic was used to test the simultaneous effect with the following formula:

$$
F=\frac{(n-k-1) R^{2}}{k\left(1-R^{2}\right)}
$$

where:

$\mathrm{n}=$ sample size

$\mathrm{k}=$ number of independent variables

$\mathrm{R}^{2}=$ coefficient of determination shows the total effect of independent variables on the dependent variable

Furthermore, the values obtained compared with the Ftable on free degree $\mathrm{k}$ and $\mathrm{n}-\mathrm{k}-1$ as well as the significance level $\alpha=0.05$. If the F-count is greater than F-table, which meaning independent variables simultaneously significant effect on the dependent variable.

For simultaneous testing, then the hypothesis is expressed in the form of statistics as follows:

$\mathrm{H}_{\mathrm{o}}: \rho_{\mathrm{YX}}=\rho_{\mathrm{YX} 2}=\ldots . \rho_{\mathrm{YX} 5}=0$ artinya tidak terdapat pengaruh dari variabel $\mathrm{X}_{1}, \mathrm{X}_{2 \ldots} \ldots \mathrm{X}_{3}$ terhadap $\mathrm{Y}$

Hi: Sekurang-kurangnya ada sebuah $\rho_{\mathrm{Xi}} \neq 0, \mathrm{i}=1,2,3$, artinya terdapat pengaruh antar variabel.

Based on the description above, the research hypothesis testing criteria partially is: if sig. 0.05 research with F-count $>$ F-table, then $\mathrm{H} 0$ is rejected and $\mathrm{H} 1$ is accepted and vice versa. If sig. Research $>$ 0.05 with F-count $<$ F-table, then $\mathrm{H} 0$ is accepted and $\mathrm{H} 1$ is rejected.

\section{FINDING AND DISCUSSION}

In accordance with the purpose of research, which is to examine the influence of experiential marketing and customer relationship marketing towards customer values, the writer has done a series of quantitative analysis which is relevant to the purpose of research.

In structural equation modeling (SEM), there are two types of models are formed, namely measurement model and structural model. The model describes the proportion of variance of each manifest variables (indicators) that can be described in a latent variable. Through the measurement model will know which one is more dominant indicator in reflecting the latent variables. After each measurement model latent variables will be elaborated further described 
structural model that will assess the effect of each independent latent variables (exogenous latent variable) to the latent variable dependent (endogenous latent variable).

\section{Measurement Model}

Using the second model of the order obtained full path diagram experiential marketing model (EM), customer kerelasian marketing (CRM) to customer value (CV) in Figure 3 as follows.

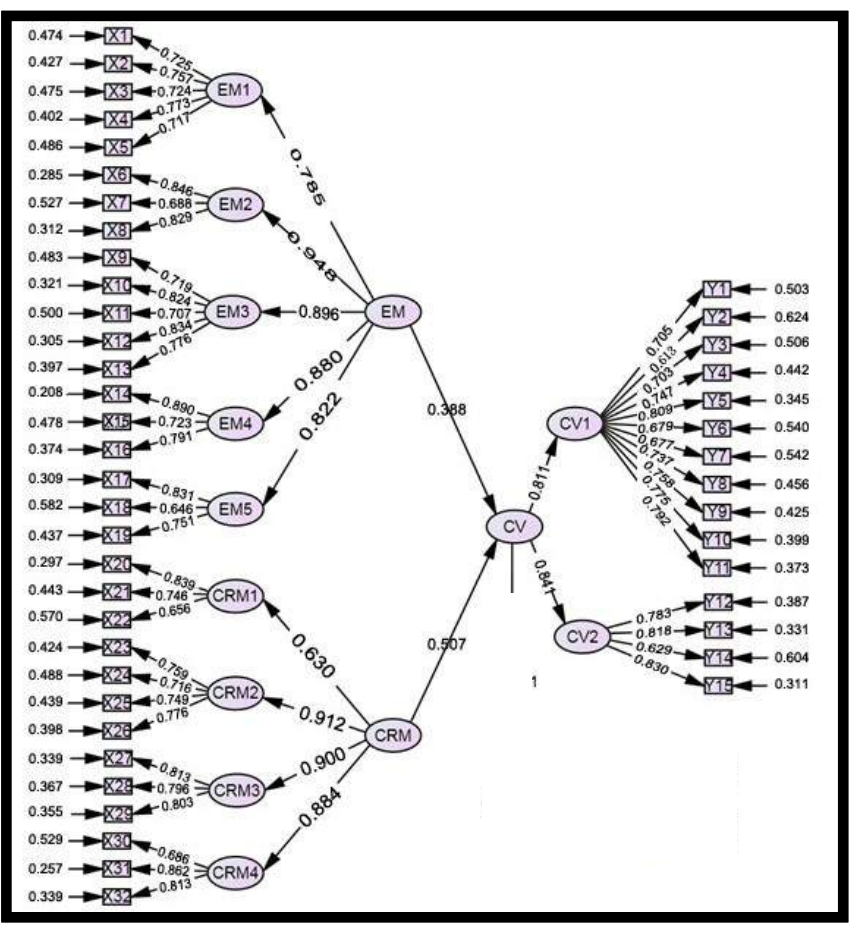

Figure 3

The coefficient of Standardization of Structural Equation Model

\section{Information :}

\section{EM = Experiential Marketing}

$\mathrm{EM}_{1} \quad=$ Sense Marketing $\quad \mathrm{EM}_{2}=$ Feel Marketing

$\mathrm{EM}_{3}=$ Think Marketing $\quad \mathrm{EM}_{4}=$ Act
Marketing $\quad \mathrm{EM}_{5}=$ Relate Marketing

CRM = Customer Relationship Marketing

$\mathrm{CRM}_{1}=$ Understanding Customer Expectation

$\mathrm{CRM}_{2}=$ Building Service Partnership $\mathrm{CRM}_{3}=$ Total Quality Management

$\mathrm{CRM}_{4}=$ Empowering Employees

CV = Customer Value

$\mathrm{CV}_{1}=$ Benefits $\quad \mathrm{CV}_{2}=$ Costs

Structural model is expressed in the following hypothesis: that the experiential marketing and customer relationship marketing significantly affect customer value either partially or simultaneously. Based on the results of data processing program
LISREL for structural model, consistent with the hypothesis put forward are as follows:

$C V=0.388 * E M+0.507 * C R M$,

Errorvar. $=0.347, R^{2}=0.653$

$$
\begin{array}{cc}
(0.060) & (0.058) \\
5.308 & 6.943
\end{array}
$$

Based on the above equation it can be explained that:

1. There is a variable degree of contribution of experiential marketing to customers who value the magnitude of 0.388 . So the better the marketing ekperiental undertaken by the hotel, it will contribute to customer value amounted to 0,388 .

2. There is a degree of contribution of customer relationship marketing towards customer value magnitude of 0.507 . So the better the customer relationship marketing, the better contribution will be to customer value of 0.507 .

The results of processing the data also showed the value of $\mathrm{R} 2$ to the above equation is equal to 0.653 , this portrait that customer value is affected simultaneously by experiential marketing and customer relationship marketing. This value also indicates that there are still other factors that affect the value of customers outside factors experiential marketing and customer relationship marketing addressed by the error variance, amounting to 0.347 . Thus the proposed conceptual hypotheses have been tested and accepted, Complete structural model for the structure:

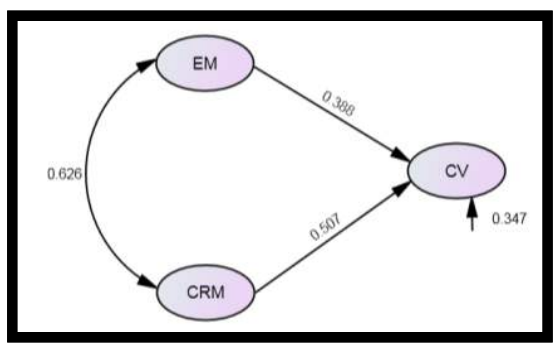

Figure 4

Path of coefficient of experiential marketing and customer relationship marketing on customer value

Table 3

Direct and Indirect Effect of Experiental Marketing and customer Relationship Marketing on Customer Value

\begin{tabular}{cccccc}
\hline & Direct & \multicolumn{2}{c}{ Indirect Effect through } \\
Variables & Effect & $\begin{array}{c}\text { Experiental } \\
\text { Marketing }\end{array}$ & $\begin{array}{c}\text { Customer } \\
\text { Relationship } \\
\text { Marketing }\end{array}$ & $\begin{array}{c}\text { Indirect } \\
\text { Effect }\end{array}$ & $\begin{array}{c}\text { Total } \\
\text { Effect }\end{array}$ \\
$\begin{array}{c}\text { Experiental } \\
\text { Marketing }\end{array}$ & $15,03 \%$ & & $12,31 \%$ & $12,31 \%$ & $27,34 \%$ \\
$\begin{array}{c}\text { Customer } \\
\text { Relationship } \\
\text { Marketing } \\
\text { Total }\end{array}$ & $25,67 \%$ & $12,31 \%$ & & $12,31 \%$ & $37,98 \%$ \\
\hline
\end{tabular}


The direct effect of the experiential marketing variable towards customer value by $15.03 \%$ while the indirect influence of $12.31 \%$, which is through variables of customers relationship marketing. The direct effect of experiential marketing towards customer value is greater than its indirect effect, this indicates that experiential marketing implemented by the company is already relatively well despite the persistence of the contribution of customer relationship marketing. Thus the influence of experiential marketing to customer value, directly or indirectly, of $27.34 \%$.

Customer relationship marketing is a variable in the model that influence either directly or indirectly on the value of customers to the direct effects of indirect $25.67 \%$ and amounted to $12.31 \%$, which is through experiential marketing. The direct effect of customer relationship marketing to customer value is greater influence than the indirect effect, this indicates that the customer relationship marketing good customer, the customer will be interested to always use the hotel in any activity is good activity official or non official. Thus the influence of customer relationship marketing to customer value, directly or indirectly, of $37.98 \%$.

Besides the two variables above there are still many other variables that give impact to customer value as based on influences outside of the model, that is equal to 0.347 , meaning that the value of customers affected by variables outside the research model by $34.7 \%$,

\section{Verifikatif Discussion}

Based on the results of data processing using SEM obtained total effect of experiential marketing and customer relationship marketing to customer value at star hotels West Java Province was 65.3 percent. The greatest impact on customer value is influenced by marketing relationship customers by 37.98 percent. Dimensional building service partnership (CRM2) is the most powerful factor in reflecting customer relationship marketing. After that followed the dimensions of total quality management (CRM3) and empowering employees (CRM4). Weakest in reflecting customer relationship marketing is understanding the dimensions of customer expectation (CRM1).

The results of this study are consistent with [2] in his research that states the responsibility of the customer to the make sure that it can a make effective use of the resource so that value can be created out of the resource purchased. [7] in his research entitled "Relationship Marketing as Key Concepts Relationship Value Determinant" states that it is Inevitable that managers adopt a relational approach to maintain relationships with Reviews their valued customers. [7] says that the hotel is a building that was created to provide lodging facilities for consumers who need a place to stay. Consumers or visitors who use the services of the hotel would always expect to get the best service from hotel services provider.

Customer value in the star hotels in the in the West Java Province was also influenced by experiential marketing up to 27.34 percent. The magnitude of these effects are caused by:

1. Indicator X4 (ability of sense of smell), the most powerful in reflecting the dimension (EM1) of experiential marketing that also affects the value of the customer.

2. Indicators X6 (Feeling with specific stimulation), the most powerful in reflecting the dimension (EM2) of experiential marketing that also affects the value of the customer.

3. Indicators $\mathrm{X} 8$ (mood), which is also strong in reflecting the dimension (EM2) of experiential marketing that also affects the value of the customer.

4. Indicators X12 (Admiration that exceeds that of surprise), the most powerful in reflecting the dimension (EM3) of experiential marketing that also affects the value of customers, the hotel West Java Province was able to make a surprise to customers by delivering something in excess of what was promised.

5. Indicators X10 (freedom of thought simultaneously), which is also strong in reflecting the dimension (EM3) of experiential marketing that also affects the value of the customer.

6. Indicators X14 (Strong interaction), which is also strong in reflecting the dimension (EM4) of experiential marketing that also affects the value of the customer.

7. Indicators X17 (idealization of a person to a product), which is also strong in reflecting the dimension (EM5) of experiential marketing that also affects the value of the customer.

Hypothesis test results of simultaneous influence of experiential marketing and customer kerelasian marketing to customer value in the West Java province is 65.3 percent, so a large $\zeta$ or major structural errors of measurement is 34.7 percent. Major structural faults such measurements are identified on the following matters:

1. The data comes from the opinion of customers who are staying at the hotel who becomes the object of research. Such conditions can lead to the opinion given by the customer only fleeting observation, that observation when customers will fill out a questionnaire. 
2. The focus of this study is limited to the implementation of experiential marketing, customer kerelasian marketing, and customer value hotel, so less attention to other conditions beyond those variables.

\section{CONCLUSION}

1. The amount of simultaneous influence of experiential marketing and customer relationship marketing to customer value in star hotels in the West Java province was 65.3 percent. The greatest impact on customer value comes from customer relationship marketing (CRM), while the smallest influence comes from experiential marketing (EM).

2. Marketing experiential effect on customer value of star hotels in the West Java province at 27.34 percent. The dimensions of experiential marketing is the most powerful in its influence is dimensional feel $\left(\mathrm{EM}_{2}\right)$.

3. Customer relationship marketing effect on customer value in star hotels in the West Java province at 37.98 percent. Dimensions of customer relationship marketing that most powerful influence is building service partnership $\left(\mathrm{CRM}_{2}\right)$.

\section{REFERENCES}

\section{Journal}

[1] Anneke Wijaya. 2014, Analisis Pengaruh Experiential Marketing Terhadap Repeat Purchase Dengan Customer Satisfaction Sebagai Mediating Variable Di De Mandailing Cafe UC Boulevard Surabaya, Jurnal Strategi Pemasaran Vol. 2, No. 1, (2014) 1-9.

[2] Chakrabarty, S., Whitten D., dan Green, K. 2011, Understanding Service Quality and Relationship Quality in is Outsourcing: Client Orientation and Promotion, Project Management Effectiveness, and The Task-TechnologyStructure Fit. Journal of Computer Information System. 48(2) : 1-15.

[3] Dauhan \& Kanaidi. 2010, Pengaruh Kualitas Jasa, Nilai Jasa, Dan Kepuasan Pelanggan Terhadap Perilaku Minat Pembelian Konsumen Pos Ekspres Di PT Pos Indonesia Wilayah Bandung Raya, ProMaRK, Jurnal Bisnis dan Pemasaran Politeknik Pos Indonesia, Vol. 2, No.1 Juni 2011

[4] Grönroos, Christian. 2011, A Service Perspective on Business Relationships: The Value Creation, Interaction and Marketing Interface,
ELSEVIER, Industrial Marketing Management Journal, 40 (2011) 240-247

[5] Isnadi, 2010. Analisis Pengaruh Customer Relationship Marketing Terhadap Nilai Pelanggan dan Keunggulan Produk Dalam Meningkatkan Kepuasan dan Loyalitas Pelanggan, Program Pasca Sarjana Universitas Diponegoro, Semarang.

[6] Jemaa, Aida Matri Ben \& Tournois, Nadine. 2014, Relationship Marketing Key Concepts as Relationship Value Determinant, IBIMA Publishing, Journal of Marketing Research and Case Studies Vol. 2014(2014).

[7] Kanaidi dan Suparno. 2010, Competitive Advantage Aspek Service Quality, Satisfaction, Trust, Reputation, Dan Customer Loyalty, The 4th PPM National Conference on Management Research Jakarta, 25 November 2010

[8] Lijia (Karen) Xie and Chih-Chien Chen. 2014, Hotel Loyalty Programs: How Valuable Is Valuable Enough?, International Journal of Contemporary Hospitality Management, Vol. 26 No. 1, 2014, pp. 107-129, Emerald Group Publishing Limited.

[9] Novy Utarie. 2013, Pengaruh Experiential Marketing Dan Relationship Marketing Terhadap Experiential Value Dan Dampaknya Terhadap Customer Behavioral Intention (Studi Kasus: Nanny's Pavillon Terrace - Central Park Mall), Binus University, Jakarta, Indonesia.

[10] Putri, Anggia Yuwandha dan Astuti, Tri Sri Rahayu. 2010, Analisis Pengaruh Experiential Marketing terhadap Loyalitas Pelanggan Hotel "X" Semarang, Aset, Februari 2010, hal. 191195 Vol. 12 No. 2.

[11] Zena, Ara Puti dan Hadisumarto, Dewanto Aswin. 2012, The Study of Relationship among Experiential Marketing, Service Quality, Customer Satisfaction, and Customer Loyalty, Asean Marketing Journal, June 2012 - Vol. IV No. 1.

\section{Books :}

[12] Cooper, Donald R., and Schindler P.S. 2009, Business Research Methods. 11ed, New York: McGraw Hill. p.236.

[13] Kotler \& Armstrong. 2010. Prinsip-prinsip Pemasaran, Jilid 1, Jakarta, Erlangga. 
[14] Kotler, Philip dan Kevin Lane Keller. 2012, Manajemen Pemasaran, Jilid 2, dialihbahasakan oleh Benjamin Molan, Jakarta, PT Indeks.

[15] Rangkuti, Freddy. 2009. Measuring Customer Satisfaction. Jakarta : PT Gramedia Pustaka Utama.

[16] Schiffman, Leon, \& Kanuk, Leslie Lazar. 2010. Consumer Behaviour (Perilaku Konsumen), Jakarta: PT. Indeks

[17] Uma Sekaran. 2009, Research Methods for Business (Metodologi Penelitian untuk Bisnis), Jakarta; Salemba Empat.

[18] Zikmund, William G., McLeod. Raymond Jr, and Gilbert, 2009. Customer Relationship, Management, Integrating Marketing Strategy and Information Technology, International Edition, Wiley.

\section{Internet sources:}

[19] http://disparbud.jabarprov.go.id (diakses tanggal 17 September 2014).

[20] http://www.parekraf.go.id (diakses tanggal 24 September 2014).

[21] http://diskominfo.jabarprov.go.id (diakses tanggal 20 September 2014).

[22] http://phri-jabar.or.id (diakses pada 15-10-2014).

[23] Kusmayadi, Tatang. 2010, Pengaruh Relationship Quality terhadap loyalitas nasabah Bank BNI. STIE STAN Indonesia Mandiri, hal.119, pada (diakses tanggal 10 September 2014). 